\title{
Procedural improvements for in vitro production of viable uterine stage caprine embryos
}

\author{
L. Keskintepe, G.C. Luvoni, S.J. Rzucidlo, B.G. Brackett * \\ Department of Physiology and Pharmacology, College of Veterinary Medicine, The University of Georgia, Athens, GA 30602-7389, USA
}

Accepted 5 October 1995

\begin{abstract}
Efforts to improve proportions of caprine immature oocytes developing into viable uterine-stage embryos in vitro involved study of 1924 oocytes in experiments designed to examine influences of fertilization media, sperm incubation temperatures, sperm treatment procedures, different protein supplementations, and different insemination intervals. Oocytecumulus complexes (OCCs) were matured during $27 \mathrm{~h}$ in TCM-199 supplemented with 20\% FBS, $100 \mu \mathrm{g} \mathrm{LH} \mathrm{ml}^{-1}, 0.5 \mu \mathrm{g}$ FSH ml ${ }^{-1}$, and $1 \mu \mathrm{g}$ Estradiol $-17-\beta \mathrm{ml}^{-1}$ at $38.5^{\circ} \mathrm{C}$ in a humidified $5 \% \mathrm{CO}_{2}, 5 \% \mathrm{O}_{2}$, and $90 \% \mathrm{~N}_{2}$ atmosphere. Freshly collected sperm were washed and incubated at either $22^{\circ} \mathrm{C}$ or $38.5^{\circ} \mathrm{C}$ for $5 \mathrm{~h}$ and then treated with either $0.1 \mu \mathrm{M}$ calcium ionophore $\mathrm{A} 23187$ for $1 \mathrm{~min}$, or with $7.35 \mathrm{mM}$ calcium lactate in the presence of oocytes during the insemination interval, or with $100 \mu \mathrm{g}$ heparin $+2 \mathrm{mM}$ caffeine $\mathrm{ml}^{-1}$ for $15 \mathrm{~min}$. The interval for insemination was experimentally varied, i.e. 14 or $24 \mathrm{~h}$. Results showed that: (a) when used as a fertilization medium mDM supported more blastocyst development than TALP ( $10.5 \%$ vs. $0 \%, P<0.05$ ); (b) incubation temperatures of $22^{\circ} \mathrm{C}$ or $38.5^{\circ} \mathrm{C}$ prepared goat spermatozoa equally for capacitation in $\mathrm{mDM}$ containing $20 \% \mathrm{FBS}$; (c) when oocytes were inseminated with sperm incubated in mDM with $20 \%$ FBS and capacitated with calcium lactate more embryos reached the blastocyst stage $(P<0.05)$ than after incubation in the same conditions but after sperm capacitation with heparin, and A23187 (31.8\% vs. $24.2 \%$ and $10.2 \%$, respectively; (d) a 24 $\mathrm{h}$ insemination interval was not superior to $14 \mathrm{~h}$ when sperm were incubated with either $20 \%$ FBS or $6 \mathrm{mg} \mathrm{BSA} \mathrm{ml}^{-1}$ and capacitated with calcium lactate $(P>0.05)$. Three morulae resulting from the best conditions in this work (FBS, calcium lactate, $14 \mathrm{~h}$ insemination) were transferred into the uterine horn ipsilateral to the corpus luteum of a recipient and two normal female kids were born after normal gestation. This is the first report in which it has been possible to consistently take caprine development to the blastocyst stage in vitro, and to obtain offspring following uterine transfer. Methodology reported here should facilitate implementation of new reproductive and genetic strategies in goat breeding.
\end{abstract}

Keywords: Caprine; Capacitation; IVF; Embryo transfer

\section{Introduction}

During the past 15 years tremendous improvements have been made in bovine IVF technology

\footnotetext{
* Corresponding author. Tel.: (706) 542-3014; fax: (706) 5423015 .
}

(Brackett and Zuelke, 1993). However, progress in caprine in vitro maturation, fertilization, and culture (IVMFC) has been relatively slow (Brackett, 1992). Difficulties in obtaining adequate numbers of oocytes have been overcome by recent progress in oocyte maturation following acquisition of ovaries at slaughter (Martino et al., 1994; Keskintepe et al., 
1994b). It is now possible to obtain live kids following transfer of embryos completely produced by IVMFC of goat oocytes (Keskintepe et al., 1994a).

An economical means for in vitro embryo production can be expected to play prominently in future goat breeding strategies. Additionally, desirability of producing in vitro goat embryos is obvious to those interested in development of biotechnologies, especially gene transfer by zygote microinjection. Producing foreign proteins via transgenic goat milk is a significant goal. Novel proteins produced in this way hold great promise for treatment of human and animal diseases (Ebert et al., 1991). Caprine IVMFC also represents a potential model for detailed study of early reproductive events and for assessing effects of a variety of influences on pregnancy and development of offspring. The present experiments, reported earlier in preliminary form (Keskintepe et al., 1994c), were carried out to establish a reliable IVMFC system for improved in vitro production (IVP) of morulae and blastocysts from goat oocytes obtained at slaughter.

\section{Materials and methods}

\subsection{Oocyte retrieval and maturation}

Ovaries were obtained at slaughter and held in PBS supplemented with $0.1 \mu \mathrm{g}$ polyvinyl alcohol (PVA, mol. wt. 30000-70 000, Sigma Chemical Co., St. Louis, MO) at $30-33^{\circ} \mathrm{C}$ during transport to the laboratory which required approximately $6 \mathrm{~h}$. In the laboratory oocyte retrieval and culture were carried out in a similar manner as described for our earlier experiments (Keskintepe et al., 1993; Keskintepe et al., 1994b). Follicles 2-6 $\mathrm{mm}$ in diameter were aspirated with a $3 \mathrm{cc}$ syringe attached to a 20 gauge needle. Then, oocytes having 2-3 layers of surrounding cumulus cells and homogeneous-appearing cytoplasm were washed $(3 \times)$ with TALP containing 0.3 mg BSA (Bovine serum albumin, essentially fatty acid free, Sigma) $\mathrm{ml}^{-1}$ (mST, Bavister et al., 1983), and randomly assigned to maturation drops. Maturation took place during a $27 \mathrm{~h}$ incubation in $100 \mu \mathrm{l}$ drops of TCM 199 (Sigma; Cat.no. M5017) prepared with $20 \%$ fetal bovine serum (FBS; Cat. no. 2306140PJ, GIBCO Laboratories, Grand Island, NY
14072), $100 \mu \mathrm{g}$ LH (NIADDK-oLH-26) $\mathrm{ml}^{-1}, 0.5$ $\mu \mathrm{g}$ FSH (NIADDK-oFSH-17) $\mathrm{ml}^{-1}$, and $1 \mu \mathrm{g}$

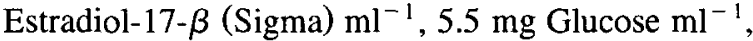
$3.6 \mathrm{mg} \mathrm{NaHCO} \mathrm{ml}^{-1}, 112 \mu \mathrm{g}^{-1}$ Pyruvate $\mathrm{ml}^{-1}$ and $50 \mu \mathrm{g}$ Gentamycin $\mathrm{ml}^{-1}$ (Keskintepe et al., 1994a). In vitro oocyte maturation and all subsequent incubations were in droplets of medium under paraffin oil (Aldrich Chemical Co., Inc., Milwaukee, WI 53233) and a humidified $5 \% \mathrm{CO}_{2}, 5 \% \mathrm{O}_{2}$ and $90 \% \mathrm{~N}_{2}$ atmosphere at $38.5^{\circ} \mathrm{C}$.

\subsection{Sperm preparation and in vitro fertilization (IVF)}

Fresh semen was obtained via an artificial vagina from three purebred Nubian bucks of proven fertility and transported to the laboratory at $33^{\circ} \mathrm{C}$ within 15 min of collection. Sperm cells were treated similarly as described by DeSmedt et al. (1992) using Defined Medium (DM),(Brackett and Oliphant, 1975) prepared without BSA but with $20 \%$ FBS and $25 \mathrm{mM}$ HEPES, modified DM (mDM), final $\mathrm{pH}$ 7.3. Briefly, sperm were washed in $\mathrm{mDM}$ by centrifugation at $320 \mathrm{~g}$ for $10 \mathrm{~min}$; after discarding supernatant washings pelleted sperm cells were overlaid with $1.5 \mathrm{ml}$ of $\mathrm{mDM}$ and allowed to swim up for $45 \mathrm{~min}$. Supernatant motile sperm fractions were then incubated for $5 \mathrm{~h}$ either at $38.5^{\circ} \mathrm{C}$ under $5 \% \mathrm{CO}_{2}, 5 \%$ $\mathrm{O}_{2}, 90 \% \mathrm{~N}_{2}$ except when these physical conditions were compared with $22^{\circ} \mathrm{C}$ under air (Experiment 2). After incubation, supernatants were discarded and gravitated sperm fractions were assessed for motility and concentration. For capacitation, sperm cells were treated with either $100 \mu \mathrm{g}$ heparin (sodium salt, Grade II from porcine intestinal mucosa, Sigma, cat. no. $\mathrm{H7005}$ ) $+2 \mathrm{mM}$ caffeine (Sigma) $\mathrm{ml}^{-1}$ for 15 min, or $0.1 \mu \mathrm{M}$ calcium ionophore A23187 (Yang et al., 1993) for $1 \mathrm{~min}$, or by exposure to $7.35 \mathrm{mM}$ calcium lactate during the insemination interval (DeSmedt et al., 1992). The calcium ionophore was prepared by combining $50 \mu \mathrm{l}$ of A23187 with $20 \mu \mathrm{l}$ dimethylsulfoxide (DMSO). This solution was used to treat sperm for $60 \mathrm{~s}$ after the incubation period. Insemination involved addition of sperm in suspension $(50 \mu 1)$ to oocytes (10 to $15 / 50 \mu l$ drop of appropriate fertilization medium). Fertilization media were sperm TALP (Parrish et al., 1986), mDM without caffeine $(\mathrm{pH} 7.6)$, or calcium lactate supple- 
mented $\mathrm{mDM}$ (described above). After A23187 treatment $3 \mathrm{mg}$ bovine serum albumin (BS $\Lambda$, Fraction V, Sigma) $\mathrm{ml}^{-1}$ was included to quench activity of the ionophore. Oocytes and sperm cells $\left(2 \times 10^{6}\right.$ motile sperm $\mathrm{ml}^{-1}$ ) were co-incubated in fertilization medium for $14 \mathrm{~h}$ or $24 \mathrm{~h}$ (insemination interval).

\subsection{In vitro culture}

Culture of presumptive zygotes and embryos was carried out by the methods reported in our earlier experiments (Keskintepe et al., 1994a; Keskintepe et al., 1994b). The medium was TCM 199 with $25 \mathrm{mM}$ HEPES (HM-199, Sigma) supplemented with $10 \%$ fetal bovine serum (FBS). The procedure for preparation of the cumulus-cell monolayer was similar to that used in our earlier bovine work (Brackett et al., 1989). Masses of cumulus cells were selected following recovery of individual oocyte-cumulus-complexes (OCC) from follicular aspirates. They were then washed through $\mathrm{mST}$ and approximately $5 \times 10^{6}$ cells $\mathrm{ml}^{-1}$ were cultured in $50 \mu \mathrm{l}$ of HM-199 at $38.5^{\circ} \mathrm{C}$ under oil and a humidified $5 \% \mathrm{CO}_{2}, 5 \% \mathrm{O}_{2}$ and $90 \% \mathrm{~N}_{2}$ atmosphere. Thirty $\mu \mathrm{l}$ of spent medium was replaced by an equal volume of fresh HM-199 every $24 \mathrm{~h}$.

\subsection{Synchronization of recipients and embryo trans- fer}

Synchronization of two mixed-breed does, each weighing approximately $35 \mathrm{~kg}$, was achieved by using norgestomet ('Synchromate B', $3 \mathrm{mg}$ total body weight; Ceva laboratories, Inc., Overland Park, Kansas 66212) as reported in bovine experiments by King et al. (1986). A $3 \mathrm{mg}$ norgestomet containing pellet was inserted under the skin of one ear and left in place for 9 days. At the time of pellet insertion each doe received $1.5 \mathrm{mg}$ norgestomet $+2.5 \mathrm{mg}$ Estradiol valerate intramuscularly. Forty-eight $h$ before ear implant removal (EIR) each doe was injected with $8 \mathrm{mg}$ dinoprost tromethamine ('Lutalyse', The Upjohn Company, Kalamazoo, MI 49001, USA). Does showed signs of estrus between 36 and $72 \mathrm{~h}$ after EIR and were prepared for aseptic surgery 5 days after detecting signs of standing estrus. Behavioural observations were for $30 \mathrm{~min}$ intervals each a.m. and p.m.
Embryo transfer was performed as previously described (Keskintepe et al., 1994a) with the exccption that embryos in this work were deposited directly into the uterine horns instead of oviducts. After entry of the peritoneal cavity, access into the uterine lumen was afforded by puncture through the myometrium using an atraumatic surgical needle. A tomcat catheter was passed through the puncture wound for embryo deposition along with approximately $50 \mu$ l culture medium. Thus, morula stage embryos were transferred directly into the uterus of each of two synchronized females.

\subsection{Experimental approaches}

\subsubsection{Experiment 1}

Initially, an experiment was carried out to confirm and extend our earlier work (Younis et al., 1991). This involved comparison of IVMFC results after use of either mDM or TALP, both prepared with 6.0 $\mathrm{mg} \mathrm{BSA} \mathrm{ml} \mathrm{m}^{-1}$ and no FBS, for in vitro insemination of in vitro matured ova with intact cumulus cells or after mechanical denudation by repeated pipeting via a finely pulled Pasteur pipet. Sperm cells were treated with $100 \mu \mathrm{g}$ heparin $+2 \mathrm{mM}$ caffeine $\mathrm{ml}^{-1}$ prior to insemination $(24 \mathrm{~h})$.

\subsubsection{Experiment 2}

Three different biochemical approaches for sperm capacitation and two different physical conditions for sperm incubations (described above) were studied for impact on IVMFC results in a $2 \times 3$ factorial design. For simplicity, treatments referred to as capacitating agents are subsequently referred to in abbreviated form as heparin, A23187, and Ca Lactate.

Controls included use of TCM $199+$ FBS for sperm treatment, deletion of FBS, and elimination of all of the putative capacitating agents to more precisely assess which components were necessary for fertilization, morula and blastocyst development. In another control the best conditions found were implemented in absence of sperm cells to assess any possible incidence of parthenogenetic development.

\subsubsection{Experiment 3}

A $2 \times 2$ factorial design was used to compare the impacts of two putative capacitating agents and presence of two protein supplements during sperm treat- 
ment and fertilization. Matured oocytes were divided into four groups and randomly assigned to one of four fertilization media, mDM with either FBS (as above) or BSA (6.0 $\left.\mathrm{mg} \mathrm{ml}^{-1}\right)$ and sperm capacitated with either calcium lactate or heparin.

\subsubsection{Experiment 4}

Effects of two capacitating agents along with two insemination intervals were investigated. $\Lambda$ fter incu bation in $\mathrm{mDM}$ (with $20 \% \mathrm{FBS}$ ) for $5 \mathrm{~h}$, sperm were capacitated with either calcium lactate or heparin. The first group of oocytes was transferred from the fertilization medium into culture at $14 \mathrm{~h}$ post-insemination and the second group, at $24 \mathrm{~h}$.

\subsection{Statistical analyses}

Each experiment was repeated at least four times. For each experiment, data included fertilization as evidenced by cleavage to two- to four-cell stage by $48 \mathrm{~h}$, morula stage development by Day 5, and blastocyst stage development noted within 7 days of post-insemination. In Experiment 4 expanded blastocyst development was noted at Day 9.

Proportions were compared by ANOVA and Bonferroni $t$-test by using a Sigma Stat software program; differences of $P<0.05$ were accepted as significant.

\section{Results}

\subsection{Experiment I}

Results provide evidence for a positive contribution of $\mathrm{mDM}$ prepared with BSA (no FBS) in contrast to mTALP for sustained viability of intact and denuded ova in this IVMFC procedure (Table 1). Development of blastocysts was achieved only after insemination of intact OCCs when IDDM was used to support fertilization. The results with denuded oocytes at the time of fertilization confirmed the importance of cumulus cells in contributing to continuing viability of embryos resulting from IVMFC.

\subsection{Experiment 2}

As shown in Table 2, better results followed use of calcium lactate than other approaches. Although there were no significant differences in fertilization resulting from sperm incubation conditions (i.e. $38.5^{\circ}$ vs. $22^{\circ} \mathrm{C}$ ) for the same capacitating agent marked differences were seen in continuing development by Day 5 when calcium lactate was employed in conjunction with the $38.5^{\circ} \mathrm{C}$ sperm incubation. The latter conditions proved superior $(P<0.05)$ for production of morulae and blastocysts. Fetal bovine serum had a positive impact on development as its inclusion was essential. Taken with controls data showed that serum (FBS) has component( $\mathrm{s}$ ) which is (are) capable (alone or in concert with other components) of inducing capacitation of sperm. Head to head agglutination observed following the $5 \mathrm{~h}$ sperm incubation suggested surface changes known to occur with capacitation. Results indicated that use of a more potent agent as the calcium ionophore A23187 along with FBS contributed to relatively poor development of in vitro fertilized caprine embryos.

Three morula stage embryos obtained following use of calcium lactate capacitated sperm were surgically transferred into the uteri of each of two hormonally synchronized recipient females. Both females became pregnant, as confirmed by ultrasonography at Day 40 after transfer, and one delivered two mixed-breed female kids following normal pregnancy.

\subsection{Experiment 3}

Incubations of sperm in $\mathrm{mDM}$, prepared with FBS or $\mathrm{BSA}$, treated with $100 \mu \mathrm{g}$ heparin $+2 \mathrm{mM}$

Table 1

Caprine morula and blastocyst development in vitro from matured oocyte cumulus complexes (OCC) left intact or denuded before in vitro fertilization and culture (Experiment 1)

\begin{tabular}{|c|c|c|c|c|}
\hline \multirow{2}{*}{$\begin{array}{l}\text { Fertilization } \\
\text { conditions } \\
\text { medium OCC }\end{array}$} & \multicolumn{4}{|c|}{ No. oocytes/embryos (\%) } \\
\hline & Inseminated & $\begin{array}{l}\text { Cleaved } \\
48 \mathrm{~h}\end{array}$ & $\begin{array}{l}\text { Morulae } \\
5 \text { days }\end{array}$ & $\begin{array}{l}\text { Blastocysts } \\
7 \text { days }\end{array}$ \\
\hline \multicolumn{5}{|l|}{$m D M^{1}$} \\
\hline Intact & 76 & $35(46.1)^{a}$ & $17(48.6)^{d}$ & $8(10.5)^{f}$ \\
\hline Denuded & 74 & $30(40.5)^{a}$ & $14(46.7)^{d}$ & $0^{g}$ \\
\hline \multicolumn{5}{|l|}{$m T A L P$} \\
\hline Intact & 77 & $20(26.0)^{b}$ & $9(45.0)^{d}$ & $0^{8}$ \\
\hline Denuded & 64 & $8(12.5)^{c}$ & $0^{e}$ & $0^{g}$ \\
\hline
\end{tabular}

${ }^{1}$ Prepared with $6.0 \mathrm{mg} \mathrm{BSA} \mathrm{ml}^{-1}$ and no FBS.

Different superscripts (a-e) within columns denote differences $(P<0.05)$. 
Table 2

Influences of sperm incubation at $38.5^{\circ} \mathrm{C}$ or $22^{\circ} \mathrm{C}$ and treatments with calcium lactate, heparin, or A23187 on results of caprine IVMFC (Experiment 2)

\begin{tabular}{|c|c|c|c|c|c|}
\hline \multirow{2}{*}{$\begin{array}{l}\text { Sperm treatments } \\
\text { Capacitating agent }\end{array}$} & \multirow[t]{2}{*}{ Temperature $\left({ }^{\circ} \mathrm{C}\right)$} & \multicolumn{4}{|c|}{ No. oocytes/embryos (\%) } \\
\hline & & Inseminated & Cleaved $48 \mathrm{~h}$ & Morulae 5 days & Blastocysts 7 days \\
\hline Ca Lactate & 38.5 & 88 & $67(76.1)^{a}$ & $48(54.5)^{\mathrm{f}}$ & $28(31.8)^{k}$ \\
\hline \multirow[t]{2}{*}{ Heparin } & 38.5 & 66 & $42(63.6)^{b}$ & $27(40.9)^{g}$ & $16(24.2)^{\prime}$ \\
\hline & 22 & 73 & $47(64.4)^{b}$ & $27(37.0) \mathrm{g}$ & $15(20.5)^{1}$ \\
\hline A23187 & 38.5 & 59 & $21(35.6)^{c}$ & $11(18.6)^{h}$ & $6(10.2)^{m}$ \\
\hline TCM $199+$ FBS $^{1}$ & 38.5 & 58 & $40(69.0)^{b}$ & $20(34.5)^{g}$ & $12(20.7)^{\prime}$ \\
\hline A23187-FBS $^{1}$ & 38.5 & 28 & $0^{\mathrm{e}}$ & $0^{i}$ & $0^{n}$ \\
\hline Heparin-FBS & 38.5 & 25 & $0^{e}$ & $0^{i}$ & $0^{n}$ \\
\hline Ca Lactate-FBS & 38.5 & 26 & $0^{\mathrm{e}}$ & $0^{i}$ & $0^{\pi}$ \\
\hline Ca Lactate-sperm & 38.5 & 26 & $0^{e}$ & $0^{i}$ & $0^{n}$ \\
\hline None & 38.5 & 30 & $0^{\mathrm{e}}$ & $0^{i}$ & $0^{\mathrm{n}}$ \\
\hline
\end{tabular}

$1+$ and - denote with or without.

Different superscripts $(\mathrm{a}-\mathrm{n})$ denote differences $(P<0.05)$.

Table 3

The impact of $20 \%$ FBS (S) or $6 \mathrm{mg} \mathrm{ml}^{-1}$ BSA (B) in combination with calcium lactate or heparin treatments for sperm and fertilization on goat IVMFC results (Experiment 3 )

\begin{tabular}{|c|c|c|c|c|c|}
\hline \multicolumn{2}{|l|}{ Sperm treatment } & \multicolumn{4}{|c|}{ No. oocytes/embryos (\%) } \\
\hline Capacitating agent & $\mathrm{S}$ or $\mathrm{B}$ & Inseminated & Cleaved $48 \mathrm{~h}$ & Morulae 5 days & Blastocyst 7 days \\
\hline Ca Lactate & $S$ & 60 & $48(80.0)^{a}$ & $24(40.0)^{e}$ & $16(26.7)^{i}$ \\
\hline Heparin & $S$ & 72 & $44(61.1)^{\mathrm{c}}$ & $24(33.3)^{2}$ & $16(22.2)^{i, 1}$ \\
\hline Heparin & B & 92 & $0^{d}$ & $0^{h}$ & $0^{\mathrm{m}}$ \\
\hline
\end{tabular}

Different superscripts $(\mathrm{a}-\mathrm{mi})$ within columns denote differences $(P<0.05)$.

Table 4

Influences of calcium lactate or heparin, $20 \% \mathrm{FBS}$ (S) or $6 \mathrm{mg} \mathrm{BSA} \mathrm{m}^{-1}$ (B), and insemination intervals of 14 or $24 \mathrm{~h}$ on results of caprine IVMFC (Experiment 4)

\begin{tabular}{|c|c|c|c|c|c|c|}
\hline $\begin{array}{l}\text { Sperm treatment } \\
S \text { or } B\end{array}$ & $\mathrm{~h}$ & \multicolumn{5}{|c|}{ No. oocytes/embryos (\%) } \\
\hline \multicolumn{7}{|l|}{ Ca Lactate } \\
\hline$S$ & 14 & 54 & $39(72.2)^{a}$ & $27(50.0)^{e}$ & $21(38.9)^{1}$ & $12(22.2)^{r}$ \\
\hline B & 24 & 78 & $39(50.0)^{\circ}$ & $30(38.5)^{f}$ & $18(23.1)^{m}$ & $9(11.5)^{\mathrm{s}}$ \\
\hline B & 14 & 57 & $39(68.4)^{a}$ & $21(36.8)^{f}$ & $18(31.6)^{1}$ & $9(15.8)^{s}$ \\
\hline \multicolumn{7}{|l|}{ Heparin } \\
\hline $\mathrm{S}$ & 24 & 108 & $21(19.4)^{c}$ & $18(16.7)^{g . h}$ & $18(16.7)^{n}$ & $0^{\prime}$ \\
\hline$S$ & 14 & 81 & $36(44.4)^{b}$ & $21(25.9) \mathrm{g}$ & $15(18.5)^{n}$ & $0^{t}$ \\
\hline B & 24 & 90 & $0^{d}$ & $0^{i}$ & $0^{\circ}$ & $0^{t}$ \\
\hline B & 14 & 96 & $15(15.6)^{c}$ & $9(9.4)^{k}$ & $3(3.1)^{P}$ & $0^{t}$ \\
\hline
\end{tabular}

\footnotetext{
${ }^{\mathrm{a}}$ Different superscripts $(\mathrm{a}-\mathrm{t})$ denote differences $(P<0.05)$.
} 
caffeine $\mathrm{ml}^{-1}$ for $15 \mathrm{~min}$ and insemination in $\mathrm{mDM}$ with $20 \%$ FBS provided inferior results to those following sperm treatment with calcium lactate and $20 \%$ FBS. When sperm were incubated in $\mathrm{mDM}$ with $\mathrm{BSA}$ results were not as good as for $\mathrm{mDM}$ with FBS. Indeed, heparin treatment in the latter conditions did not allow IVF to occur (T'able 3). These results indicate FBS supplementation to sperm media was critical. The capacitating agent was also an important factor in resulting cleavage, morula, and blastocyst development of caprine oocytes carried through IVMFC.

\subsection{Experiment 4}

Incorporation of calcium lactate in $\mathrm{mDM}$ for insemination provided superior conditions to sperm treatment with heparin in absence of FBS prior to insemination in $\mathrm{mDM}$ without calcium lactate (Table 4). Inclusion of FBS provided better results than BSA. Cleavage rates were higher $(P<0.05)$ when the insemination interval was $14 \mathrm{~h}$ instead of $24 \mathrm{~h}$ except when calcium lactate and FBS were present (Table 4). The latter conditions afforded the highest proportions of blastocyst and expanded blastocyst development.

\section{Discussion}

The results show that immature oocytes collected from ovaries of slaughtered goats can be fertilized and cultured up to the expanded blastocyst stage. Further, the method for consistently obtaining viable caprine development to the blastocyst stage in vitro was documented by live offspring following uterine transfer. The average percentage of immature oocytes reaching the blastocyst stage in best conditions found in the present work was $38.9 \%$. Farlier results (Younis et al., 1991) demonstrating superiority of mDM over mTALP at fertilization were confirmed and extended (Table 1). Also, capacitation following insemination in the presence of calcium lactate proved better than sperm treatments with either heparin or the calcium ionophore A23187. Most probably the FBS used for incubation of sperm for $5 \mathrm{~h}$ affected sperm to initiate the capacitation process as head to head agglutination could be observed by light microscopy just after incubation. Thus, it appears likely that additional use of more potent capacitating agents, e.g. A23187, heparin, could 'over capacitate' and hence damage the sperm and deter its functional ability.

The results obtained (Table 1) were better for oocytes with cumulus cells at the time of fertilization, and exceeded those achieved by Younis et al. (1992). In contrast to the report of DeSmedt et al. (1992) the cumulus cells were confirmed to play an important role in fertilization and continued viability as demonstrated earlier for bovine IVF (Brackett et al., 1989).

With calcium lactate and $\mathrm{FBS}$ present, $38.5^{\circ} \mathrm{C}$ proved to be better than the other treatments for incubating sperm as evidenced by significantly higher proportions of immature oocytes reaching morula and blastocyst stages (Table 2). Good results have been reported at $38.5^{\circ} \mathrm{C}$ (Crozet et al., 1987). Sperm incubation temperatures, $22^{\circ} \mathrm{C}$ or $38.5^{\circ} \mathrm{C}$, for $5 \mathrm{~h}$ were not associated with significant differences $(P$ $<0.05$ ) in fertilization rates but viability was positively affected subsequently by sperm incubation at $38.5^{\circ} \mathrm{C}$, at least under the best conditions used in the present work (Table 2).

Calcium lactate provided better preparation for sperm than did the heparin treatment and FBS was superior to BSA (Table 3). Recent improvements in bovine embryo culture in defined conditions (Trounson et al., 1994; Brackett and Keskintepe, 1994) have demonstrated that sera and coculture cells could be eliminated by using synthetic oviductal fluid. Recently, no differences were detected in functional ability of sperm or in ovum development after use of sera obtained from either a proestrus cow, or a steer, or FBS for sperm incubation, fertilization, and culture of goat embryos (Keskintepe, L. and Brackett, B.G., unpublished). Contributions of sera deserve further study in efforts to replace them with defined components for caprine IVMFC. Immature mammalian embryos can mature in $23-27 \mathrm{~h}$ in vitro (Watson et al., 1992). A maturation interval of $27 \mathrm{~h}$ was found to be superior for caprine oocytes (DeSmedt et al., 1992; Kcskintepe ct al., 1993; Martino et al., 1994). The best insemination intervals for mammalian IVMFC were indicated as $24 \mathrm{~h}$ for bovine (Younis et al., 1991), $18 \mathrm{~h}$ for sheep (Crozet et al., 1987), and 18-24 h for goat (DeSmedt et al., 1992, 
Keskintepe et al., 1993). The results presented here revealed that a $14 \mathrm{~h}$ insemination interval was sufficient yielding results that were not different from those afforded by a $24 \mathrm{~h}$ interval (Table 4).

Improvements in procedure enabled consistent IVP of goat uterine stage embryos. Two pregnancies confirmed by real time ultrasonography 40 days after transfer followed two embryo transfer attempts. Twin female kids wcre born following a normal gestation period thereby establishing feasibility for direct uterine transfer of caprine embryos produced by complete IVMFC.

\section{Conclusions}

In vitro insemination of intact COCs in $\mathrm{mDM}$ provided better IVMFC results, including blastocyst development, than when denuded oocytes, or TALP were used (Experiment 1).

Sperm incubation at $38.5^{\circ} \mathrm{C}$ with capacitation and insemination in the presence of calcium lactate with FBS supplementation provided better IVMFC results (31.8\% development to blastocysts) than when heparin or A23187 were employed as capacitating agents (Experiment 2). A recipient doe gave birth to two normal female kids after transfer of morulae resulting from these conditions. FBS supplementation during sperm preparation (by any approach investigated) was necessary for fertilization to take place.

Incubations of sperm in $\mathrm{mDM}$, prepared with FBS or BSA, treated with $100 \mu \mathrm{g}$ heparin $+2 \mathrm{mM}$ caffeine and insemination in $\mathrm{mDM}$ with $20 \% \mathrm{FBS}$ provided inferior results to those following calcium lactate and 20\% FBS (Expcriment 3). FBS supplementation and the capacitating agent were important factors in sustaining caprine development in vitro.

Improved results followed supplementation with FBS (vs. BSA) when heparin or calcium lactate were capacitating agents. Cleavage rates were higher when the insemination interval was $14 \mathrm{~h}$ instead of $24 \mathrm{~h}$ except when calcium lactate and FBS were present, i.e. optimal conditions found (Experiment 4).

\section{Acknowledgements}

Authors gratefully acknowledge support of UGA VMES 94-208, and Transgenic Products, Inc., At- lanta, GA. Appreciation is also expressed to National Hormone and Pituitary Program, NIDDK, NICHD, and USDA for oLH; Rock Creek Sausage, Inc. for oocytes; and Joanne Foster for secretarial assistance.

\section{References}

Bavister, B.D., Leibfried, M.L. and Lieberman, G., 1983. Development of preimplantation embryos of the golden hamster in a defined culture medium. Biol. Reprod., 28: 235-247.

Brackett, B.G., 1992. In vitro fertilization in farm animals. In: A. Lauria and F. Gandolfi, (Editors), Intemational Symposium on Embryonic Technology in Domestic Species: Trends in Research and Applications, Portland Press, Chapel Hill, NC, pp. $59-76$.

Brackett, B.G. and Keskintepe, L., 1994. Improved culture conditions for in vitro production of bovine blastocysts. J. Reprod. Fert. Abstr., ser. 13: 13-14 (Abstr. 34).

Brackett, B.G. and Oliphant, G., 1975. Capacitation of rabbit spermatozoa in vitro. Biol. Reprod., 12: 260-274.

Brackett, B.G. and Zuelke, K.A., 1993. Analysis of factors involved in the in vitro production of bovine embryos. Theriogenology, 39: 43-64.

Brackett, B.G., Younis, A.I. and Fayrer-Hosken, R.A., 1989. Enhanced viability after in vitro fertilization of bovine oocytes matured in vitro with high concentration of luteinizing hormone. Fertil. Steril., 52: 319-324.

Crozet, N., Huneau, D., DeSmedt, V., Theron, M.C., Szollosi, D., Torres, S. and Svellec, C., 1987. In vitro fertilization with normal development in the sheep. Gamete Res., 16: 159-170.

DeSmedt, V., Crozet, N., Ahmed-Ali, M., Martino, A. and Cognie, Y., 1992. In vitro maturation and fertilization of goat oocytes. Theriogenology, 37: 1049-1060.

Ebert, K.M., Selgarth, J.P., DiTullio, P., Denman, J., Smith, T.E., Memon, J.P., Schindler, J.E., Monastersky, G.M., Vitale, J.A. and Gordon, K., 1991. Transgenic production of a variant of human tissue-type plasminogen activator in goat milk: Generation of transgenic goats and analysis of expression. Biotechnology, 9: 835-838.

Keskintepe, L. and Brackett, B.G., unpublished. Author to supply details.

Keskintepe, L., Darwish, G., Kenimer, A. and Brackett, B.G., 1994a. Term development of caprine embryos obtained from immature oocytes. Theriogenology, 42: 527-535.

Keskintepe, L., Darwish, G., Paramio, M. and Brackett, B.G., 1993. Caprine oocyte fertilization and development in vitro. Biol. Reprod., 41 (Suppl. 1) $\Lambda$ bst. $45 !$

Keskintepe, L., Darwish, G., Younis, A.I. and Brackett, B.G., 1994b. In vitro development of morulae from immature caprine oocyles. Zygute, 2: 96-107.

Keskintepe, L., Luvoni, G.C., Bassiony, M.M., Brackett, B.G., 1994c. In vitro caprine blastocyst development from immature oocytes. Biol. Reprod., 50: Abst 537, p. 189.

King, M.E., Odde, K.G., LeFever, D.G., Brown, N. and Neubauer, C.J., 1986. Synchronization of estrus in embryo transfer recip- 
ients receiving demi-embryos with synchro-mate B or estrumate. Theriogenology, 26: 221-229.

Martino, A., Mogas, T., Palamo, M.J. and Paramio, M.T., 1994. Meiotic competence of prepubertal goat oocytes. Theriogenology, 41: 969-980.

Parrish, J.J., Susko-Parish, J.L., Leibfried-Rutledge, M.L., Critser, E.S., Eyestone, W.H. and First, N.L., 1986. Bovine in vitro fertilization with frozen-thawed semen. Theriogenology, 25: $591-600$.

Trounsen, A., Pushett, D., Maclellan, L.J., Lewis, I. and Gardner, D.K., 1994. Current status of IVM/IVF and embryo culture in humans and farm animals. Theriogenology, 41: 57-66.

Watson, A.J., Hogan, A., Hahnel, A. and Schultz, G.A., 1992.
Activation of the embryonic genome: Comparisons between mouse and bovine development. In: Barry D. Bavister (Editor), Preimplantation Embryo Development, Springer-Verlag, NY, pp. 115-131.

Yang, X., Jiang, S. and Foote, R.H., 1993. Bovine oocyte development following different oocyte maturation and sperm capacitation procedures. Mol. Reprod. Dev., 34: 94-100.

Younis, A.I., Kcskintcpc, L., Mackie, K. and Brackett, B.G., 1992. In vitro maturation and fertilization of Toggenburg oocytes. Theriogenology, 37: 330 .

Younis, A.I., Zuelke, K.A., Harper, KM., Oliveria, M.A.L. and Brackett, B.G., 1991. In vitro fertilization of goat oocytes. Biol. Reprod., 44: 1177-1182. 